\title{
Pentingnya Manajemen Risiko dalam dunia Pendidikan (Sekolah) Selama dan Pasca Covid-19
}

\author{
Maximus Ali Perajaka: STIM SAINT MARY \\ Yohanes Ngamal: STIM SAINT MARY \\ Email:yohanesngamal05@gmail.com
}

\begin{abstract}
Abstrak:
Studi ini mempelajari mengenai konsep dan penerapan manajemen risiko, secara khusus dalam bidang Pendidikan (sekolah). Topik ini dipilih karena, pandemic Covid-19 telah menimbulkan dampak yang sangat luas dan mendalam pada bidang Pendidikan, sehingga sekitar 80 persen para guru dan siswa di tingkat global, dan sekitar 90 -an persen sekolah di Indonesia pernah ditutup untuk kegiatan pembelajaran tatap muka.

Studi ini terasa semakin penting, karena saat ini, Ketika tren penyebaran Covid-19 mulai melandai, otoritas Pendidikan (Kemendikbudristed) dan penyelenggara dan/atau pengelola sekolah bersiap-siap membuka kembali sekolah. Ketika sekolah Kembali dibuka, maka otoritas bersama penyelenggara dan/atau pengelola sekolah perlu menerapkan manajemen risiko secara lebih serius guna mencegah agar sekolah tidak Kembali menjadi kluster penyebaran Covid-19 gelombang baru.
\end{abstract}

Kata kunci: covid-19, dunia pendidikan; sekolah; manajemen risiko

\section{PENDAHULUAN}

\section{I.I Latar Belakang}

Pandemi coronavirus (COVID-19) telah menyebabkan krisis yang belum pernah terjadi sebelumnya di semua bidang. Di bidang pendidikan, keadaan darurat ini menyebabkan penutupan besar-besaran kegiatan pembelajaran tatap muka.

Secara global, penutupan lembaga pendidikan terjadi di lebih dari 190 negara, dengan tujuan untuk mencegah penyebaran virus dan mengurangi dampaknya. Menurut data dari United Nations Educational, Scientific and Cultural Organization (UNESCO), sedikitnya ada 127 juta sekolah di dunia yang terdampak Covid-19, lebih dari I,2 miliar siswa di semua tingkat pendidikan di seluruh dunia telah berhenti mengikuti kelas tatap muka.

Sementara itu, UNESCO telah mengidentifikasi kesenjangan besar dalam hasil pendidikan, yang terkait dengan distribusi guru yang tidak merata pada umumnya, dan guru dengan kualifikasi terbaik pada khususnya, yang merugikan negara dan wilayah berpenghasilan rendah dan daer- 
ah pedesaan, di mana penduduk asli dan populasi migran cenderung terkonsentrasi (UNESCO, 2016a; Messina dan García, 2020).

Di Indonesia, Kementerian Pendidikan, Kebudayaan dan Riset Teknologi (Kemdikbudristek) menyatakan jumlah sekolah yang terdampak Covid-19 di Indonesia sebanyak 407.000 sekolah, 3,4 juta guru serta 56 juta siswa. Kemdikbudristek menyatakan dampak pandemi Covid-19 menyebabkan risiko anak putus sekolah meningkat. Kondisi ini diperparah oleh persepsi masyarakat tentang peranan sekolah pada pembelajaran jarak jauh (PJJ). Dampak lainnya terhadap pendidikan di antaranya siswa ketinggalan pelajaran, serta meningkatnya tingkat stres pada anak-anak.

Memang, banyak tindakan yang diambil oleh negara-negara di dunia, termasuk Indonesia untuk menanggapi krisis yang diakibatkan oleh Covid-19 itu. Langkah yang diambil antara lain melakukan penangguhan kelas tatap muka di semua tingkatan. Langkah tersebut telah memunculkan tiga bidang tindakan utama: penyebaran modalitas pembelajaran jarak jauh melalui berbagai format dan platform (dengan atau tanpa penggunaan teknologi); dukungan dan mobilisasi tenaga kependidikan dan masyarakat; dan kepedulian terhadap kesehatan dan kesejahteraan siswa secara keseluruhan.

Pada Maret 2020I lalu, epidemiolog asal Griffith University Australia, Dicky Budiman, meminta pemerintah menyiapkan manajemen risiko terkait rencana dimulainya sekolah tatap muka terbatas. Dicky mengatakan program tersebut harus detail dan jelas, sebagai pegangan stakeholder di masing-masing sekolah tentang kesiapan rencana sekolah tatap muka, protokol kesehatan, dan standar kapan rem darurat mesti diambil jika terjadi kasus penyebaran Covid-19 saat kegiatan sekolah tatap muka berlangsung. Dalam program manejemen risiko tersebut, Dicky melanjutkan, ada beberapa elemen yang harus masuk didalamnya. Pertama, membangun kerjasama antar lembaga mulai dari tingkat pusat hingga daerah, untuk mempersiapkan, mengawasi, dan mengevaluasi jalannya sekolah tatap muka.'

Pertanyaannya, apakah dalam masa pandemi Covid-19, dunia pendikan (sekolah-sekolah) menerapkan pendekatan manajemen risko? Kalau pun sudah ada, bagaimana pendekatan itu dipraktikan? Kalaupun belum, Langkah apakah yang pendekatan manajemen risiko yang seharusnya diambil?

Tujuan dari penelitian dan penulisan ini adalah untuk menjelaskan bagaimana menerapkan manajemen risiko

I. Tatang Guritno. "Epidemiolog Minta Pemerintah Siapkan Manajemen Risiko Sekolah Tatap Muka Kompas.com - 31/03/202I. Diakses, Rabu, 0I September 2021, pukul 17.00. atas dampak Covid-19 pada komunitas pendidikan dalam jangka pendek dan menengah, dan untuk menawarkan rekomendasi utama tentang bagaimana mengelola konsekuensi tersebut dengan cara terbaik, menarik perhatian pada kesempatan untuk belajar dan inovasi dalam sistem pendidikan pascapandemi.

\section{II.TINJAUAN PUSTAKA}

\section{I Manajemen Risiko \\ 2.I.I Definisi}

Risk Management (manajemen risiko) adalah topik yang penting dan memberikan kedalaman yang unik dan pengaruh yang kuat dalam beberapa tahun terakhir. Berdasarkan pemikiran terbaru dalam tata kelola organisasi, perusahaan, ekonomi perilaku, sumber daya manusia dan risiko operasional, manajemen risiko dapat didefinisikan sebagai risiko bahwa orang tidak mengikuti prosedur, praktik, dan/atau aturan organisasi, sehingga menyimpang dari perilaku yang diharapkan dengan cara yang dapat merusak kinerja dan reputasi organisasi sosial dan bisnis. Topik ini meliputi berbagai isu mulai dari aksi penipuan hingga keputusan bisnis yang buruk, aktivitas ilegal hingga tata kelola organisasi/ perusahaan yang longgar sehingga menghadirkan tantangan yang berkembang di organisasi yang kompleks dan tersebar saat ini.

Penulis Keith Blacker, Patrick McConnell mendefisikan manajemen risiko sebagai proses mengidentifikasi, menilai, dan mengendalikan ancaman terhadap modal dan pendapatan organisasi. Ancaman atau risiko ini dapat berasal dari berbagai sumber, termasuk ketidakpastian keuangan, kewajiban hukum, kesalahan manajemen strategis, kecelakaan, dan bencana alam. ${ }^{2}$

Ancaman keamanan teknologi informasi (TI) dan risiko terkait data, serta strategi manajemen risiko untuk mengatasinya, telah menjadi prioritas utama bagi perusahaan digital. Akibatnya, rencana manajemen risiko semakin mencakup proses perusahaan untuk mengidentifikasi dan mengendalikan ancaman terhadap aset digitalnya, termasuk data perusahaan yang dipatenkan, informasi pengenal pribadi (PII) pelanggan, dan kekayaan intelektual.

Setiap organisasi, baik social maupun bisnis menghadapi risiko kejadian tak terduga dan berbahaya yang dapat merugikan perusahaan atau menyebabkan perusahaan tutup secara permanen. Manajemen risiko memungkinkan organisasi untuk mencoba mempersiapkan hal yang tidak terduga dengan meminimalkan risiko dan biaya tambahan

2. Keith Blacker, Patrick McConnell .2016."People Risk Management A Practical Approach to Managing the Human Factors That Could Harm Your Business.” Kogan Page, Limited. Hal I5. 
sebelum terjadi.

Dengan menerapkan rencana manajemen risiko dan mempertimbangkan berbagai potensi risiko atau peristiwa sebelum terjadi, organisasi dapat menghemat uang dan melindungi masa depan mereka. Ini karena rencana manajemen risiko yang kuat akan membantu perusahaan menetapkan prosedur untuk menghindari potensi ancaman, meminimalkan dampaknya jika terjadi dan mengatasi hasilnya. Kemampuan untuk memahami dan mengendalikan risiko ini memungkinkan organisasi untuk lebih percaya diri dalam keputusan bisnis mereka.

Selain itu, prinsip tata kelola perusahaan yang kuat yang berfokus secara khusus pada manajemen risiko dapat membantu perusahaan mencapai tujuannya. Manfaat penting lainnya dari manajemen risiko meliputi: ${ }^{3}$

- Menciptakan lingkungan kerja yang aman dan terjamin untuk semua staf dan pelanggan.

- Meningkatkan stabilitas operasi bisnis sekaligus mengurangi tanggung jawab hukum.

- Memberikan perlindungan dari kejadian yang merugikan baik bagi perusahaan maupun

- lingkungan.

- Melindungi semua orang dan aset yang terlibat dari potensi bahaya.

- Membantu menetapkan kebutuhan asuransi organisasi untuk menghemat premi yang tidak perlu.

Pentingnya menggabungkan manajemen risiko dengan keselamatan pasien juga telah terungkap. Di sebagian besar rumah sakit dan organisasi, departemen manajemen risiko dan keselamatan pasien dipisahkan; mereka menggabungkan kepemimpinan, tujuan, dan ruang lingkup yang berbeda. Namun, beberapa rumah sakit menyadari bahwa kemampuan untuk memberikan perawatan pasien yang aman dan berkualitas tinggi diperlukan untuk melindungi aset keuangan dan, sebagai hasilnya, harus digabungkan dengan manajemen risiko.

Pada tahun 2006, Virginia Mason Medical Center di Seattle, Washington mengintegrasikan fungsi manajemen risiko mereka ke dalam departemen keselamatan pasien mereka, yang pada akhirnya menciptakan metode manajemen Virginia Mason Production System (VMPS). VMPS berfokus untuk terus meningkatkan sistem keselamatan pasien dengan meningkatkan transparansi dalam mitigasi, pengungkapan, dan pelaporan risiko. Sejak menerapkan sistem baru ini,Virginia Mason telah mengalami penurunan yang signifikan dalam premi profesional rumah sakit dan peningkatan besar dalam budaya pelaporan.

3. Ibid

\section{I.2 Strategi pendekatan dan proses manaje- men risiko}

Ada kesalahpahaman umum tentang manajemen risiko bahwa tujuan manajemen risiko adalah untuk sepenuhnya menghilangkan risiko dari bisnis. Ini tidak sepenuhnya benar karena penghapusan risiko praktis tidak mungkin. Sebaliknya, tujuan manajemen risiko adalah pertama-tama memastikan bahwa organisasi memiliki gambaran yang jelas tentang tingkat risiko yang bersedia mereka ambil dan kemudian memastikan bahwa risiko tetap berada dalam batas-batas tersebut.

jika ditanyakan kepada manajemen suatu organisasi apakah mereka ingin mengurangi risiko di organisasi mereka, jawabannya, kemungkinan besar, akan tegas ya! Namun, perlu dipahami bahwa manajemen risiko tidak bekerja seperti 'magic'. Ada hubungan yang jelas dan langsung antara risiko dan imbalan. Oleh karena itu, jika organisasi ingin meminimalkan risiko, ada kemungkinan besar bahwa mereka akan meminimalkan imbalan juga. $\mathrm{Di}$ sinilah segalanya menjadi rumit! Ada organisasi tertentu yang ingin tumbuh dengan cepat. Oleh karena itu, menurut definisi, mereka harus mengambil lebih banyak risiko untuk memungkinkan organisasi mencapai pertumbuhan yang lebih cepat. Yang penting, organisasi perlu menyadari hubungan antara risiko dan imbalan ini. Memiliki kebijakan minimalisasi risiko dan maksimalisasi penghargaan dapat menjadi tidak konsisten dan dapat menciptakan hasil negatif.

Sebagaimana disebutkan sebelumnya, manajemen risiko adalah proses mengidentifikasi risiko, menilai risiko, dan mengambil langkah-langkah untuk mengurangi risiko ke tingkat yang dapat diterima. Pendekatan manajemen risiko menentukan proses, teknik, alat, dan peran dan tanggung jawab tim untuk proyek tertentu. Rencana manajemen risiko menggambarkan bagaimana manajemen risiko akan terstruktur dan dilakukan pada proyek.

Sebagai proses manajemen, manajemen risiko digunakan untuk mengidentifikasi dan menghindari potensi biaya, jadwal, dan kinerja/risiko teknis pada suatu sistem, mengambil pendekatan proaktif dan terstruktur untuk mengelola hasil negatif, menanggapinya jika terjadi, dan mengidentifikasi peluang potensial yang mungkin tersembunyi dalam situasi tersebut. Pendekatan dan rencana manajemen risiko mengoperasionalkan tujuan manajemen ini.

Secara teoritis, ada pendekatan yang berbeda untuk manajemen risiko yang menghasilkan berbagai jenis hasil bagi organisasi yang terlibat. Oleh karena itu, organisasi harus memilih pendekatan mana yang ingin diikuti

Pada hakekatnya, setelah mengidentifikasi risiko spe- 
sifik organisasi/lembaga atau perusahaan dapat menerapkan proses manajemen risiko. Secara prinsip ada beberapa strategi berbeda yang dapat diambil organisasi/perusahaan terkait dengan berbagai jenis risiko. Strategi-strategi pendekatan dan proses langkah-langkah dasar manajemen risiko tampak seperti pada gambar I berikut: ${ }^{4}$

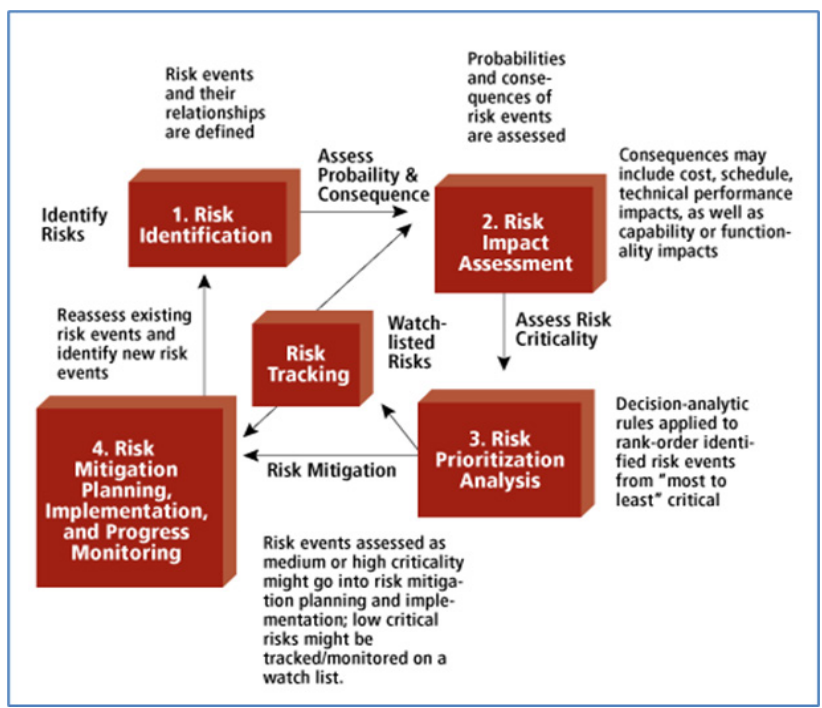

Gambar I: Tahap-Tahap Dasar dalam Penerapan Risiko Manajemen

(Sumber:SEG Tim, Risk Management Approach and Plan, dalam /www.mitre.org).

Semua rencana manajemen risiko mengikuti langkah-langkah yang sama yang digabungkan untuk membentuk proses manajemen risiko secara keseluruhan:

- Tetapkan konteks. Pahami keadaan di mana sisa proses akan berlangsung. Kriteria yang akan digunakan untuk mengevaluasi risiko juga harus ditetapkan dan struktur analisis harus ditentukan.

- Identifikasi resiko. Perusahaan mengidentifikasi dan mendefinisikan risiko potensial yang dapat berdampak negatif terhadap proses atau proyek perusahaan tertentu.

- Analisis resiko. Setelah jenis risiko tertentu diidentifikasi, perusahaan kemudian menentukan kemungkinan terjadinya risiko tersebut, serta konsekuensinya. Tujuan dari analisis risiko adalah untuk lebih memahami setiap contoh spesifik dari risiko, dan bagaimana hal itu dapat mempengaruhi proyek dan tujuan perusahaan.

4. National Institute of Standards and Technology, July 2002, Risk Management Guide for Information Technology System, Special Publication 800-30, hal. I.
- Penilaian dan evaluasi risiko. Risiko tersebut kemudian dievaluasi lebih lanjut setelah menentukan kemungkinan terjadinya risiko secara keseluruhan dikombinasikan dengan konsekuensi keseluruhannya. Perusahaan kemudian dapat mengambil keputusan apakah risiko tersebut dapat diterima dan apakah perusahaan bersedia mengambilnya berdasarkan selera risikonya.

- Mitigasi risiko. Selama langkah ini, perusahaan menilai risiko peringkat tertinggi mereka dan mengembangkan rencana untuk menguranginya menggunakan kontrol risiko khusus. Rencana ini mencakup proses mitigasi risiko, taktik pencegahan risiko, dan rencana kontinjensi jika risiko membuahkan hasil.

- Pemantauan risiko. Bagian dari rencana mitigasi termasuk menindaklanjuti risiko dan rencana keseluruhan untuk terus memantau dan melacak risiko baru dan yang sudah ada. Proses manajemen risiko secara keseluruhan juga harus ditinjau dan diperbarui.

- Berkomunikasi dan berkonsultasi. Para pemangku kepentingan (stakeholders) organisasi, atau para pemegang saham (shareholders) internal dan eksternal perusahaan harus dilibatkan dalam komunikasi dan konsultasi pada setiap langkah yang tepat dari proses manajemen risiko dan dalam kaitannya dengan proses secara keseluruhan. ${ }^{5}$

\section{I.3 Peran manajemen risiko}

Manajemen risiko srategis juga mencoba menjawab pertanyaan-pertanyaan berikut: Apa yang bisa salah?' Apa pertimbangkan yang dipakai untuk mengatasi masalah, baik tempat kerja secara keseluruhan dan pekerjaan individu?; Bagaimana pengaruhnya terhadap organisasi? Apakah kemungkinan yang bakal terjadi dan apakah itu akan berdampak besar atau kecil bagi organisasi dan invidu anggotanya? Apa yang bisa dilakukan? Langkah-langkah apa yang dapat diambil untuk mencegah kerugian? Apa yang bisa dilakukan untuk memulihkan jika terjadi kerugian? Jika sesuatu terjadi, bagaimana organisasi akan mengatasi, termasuk bagaimana organisasi membiayai kerugian tersebut?

\section{I.4 Keunggulan dan Keterbatasan manaje- men risiko}

Pada galibnya, manajemen risiko dikembangkan atau diterapkan dalam suatu organisasi karena membawa keuntungan/keunggulan. Rufina Scott (2019) menyebutkan beberapa keunggulan manajemen risiko sebagai berikut: ${ }^{6}$

5. Ibid

6. Rufina Scott (202I), "Risk Management: Objectives, Advantages And Disadvantages" dalam http://processnews.blogspot.com/2019, diakses, Kamis, 02 September 202I, pukul 16.I3.WIB. 
I) Mendorong perusahaan untuk memikirkan ancamannya. Secara khusus, manajemen risiko mendorongnya untuk menganalisis risiko yang mungkin diabaikan.

2) Dalam mengklarifikasi risiko, mendorong perusahaan untuk lebih siap. Dengan kata lain, ini membantu perusahaan untuk mengelola dirinya sendiri dengan lebih baik.

3) Memungkinkan organisasi memprioritaskan investasinya dan mengurangi perselisihan internal tentang bagaimana uang harus dibelanjakan.

4) Mengurangi duplikasi sistem. Integrasi sistem lingkungan dan kesehatan dan keselamatan adalah salah satu contohnya

Sementara manajemen risiko dapat menjadi praktik yang sangat bermanfaat bagi organisasi, keterbatasannya juga harus dipertimbangkan. Banyak teknik analisis risiko -- seperti membuat model atau simulasi memerlukan pengumpulan data dalam jumlah besar. Pengumpulan data yang ekstensif ini bisa mahal dan tidak dijamin dapat diandalkan.

Selain itu, penggunaan data dalam proses pengambilan keputusan mungkin memiliki hasil yang buruk jika indikator sederhana digunakan untuk mencerminkan realitas situasi yang jauh lebih kompleks. Demikian pula, mengadopsi keputusan di seluruh proyek yang dimaksudkan untuk satu aspek kecil dapat menyebabkan hasil yang tidak terduga.

Keterbatasan lainnya adalah kurangnya keahlian analisis dan waktu. Program perangkat lunak komputer telah dikembangkan untuk mensimulasikan peristiwa yang mungkin berdampak negatif pada perusahaan. Meskipun hemat biaya, program kompleks ini membutuhkan personel terlatih dengan keterampilan dan pengetahuan yang komprehensif untuk memahami hasil yang dihasilkan secara akurat. Menganalisis data historis untuk mengidentifikasi risiko juga membutuhkan personel yang sangat terlatih. Orang-orang ini mungkin tidak selalu ditugaskan ke proyek. Kalaupun ada, seringkali tidak cukup waktu untuk mengumpulkan semua temuan mereka, sehingga menimbulkan konflik.

Keterbatasan lainnya termasuk: ${ }^{7}$

- Rasa stabilitas yang salah. Pengukuran nilai-berisiko berfokus pada masa lalu, bukan masa depan. Oleh karena itu, semakin lama semuanya berjalan lancar, semakin baik situasinya. Sayangnya, ini membuat penurunan lebih mungkin terjadi.

- Ilusi kontrol. Penilaian risiko kualitatif bersifat subjektif dan kurang konsisten. Model manajemen risiko dapat memberi organisasi keyakinan palsu bahwa mereka

7. Ibid. dapat mengukur dan mengatur setiap potensi risiko. $\mathrm{Hal}$ ini dapat menyebabkan organisasi mengabaikan kemungkinan risiko baru atau tidak terduga. Selain itu, tidak ada data historis untuk produk baru, jadi tidak ada pengalaman untuk dijadikan dasar model.

- Kegagalan untuk melihat gambaran besarnya. Sulit untuk melihat dan memahami gambaran lengkap tentang risiko kumulatif.

- Manajemen risiko belum matang. Kebijakan manajemen risiko organisasi kurang berkembang dan tidak memiliki sejarah untuk membuat evaluasi yang akurat.

- Menghabiskan terlalu banyak waktu untuk menilai dan mengelola risiko yang tidak mungkin dapat mengalihkan sumber daya yang dapat digunakan secara lebih menguntungkan.

\subsubsection{Standar manajemen risiko}

Sejak awal 2000-an, beberapa industri dan badan pemerintah telah memperluas aturan kepatuhan peraturan yang meneliti rencana, kebijakan, dan prosedur manajemen risiko perusahaan. Dalam peningkatan jumlah industri, dewan direksi diminta untuk meninjau dan melaporkan kecukupan proses manajemen risiko perusahaan. Akibatnya, analisis risiko, audit internal dan cara penilaian risiko lainnya telah menjadi komponen utama dari strategi bisnis.

Standar manajemen risiko telah dikembangkan oleh beberapa organisasi, termasuk National Institute of Standards and Technology (NIST) dan International Organization for Standardization (ISO). ${ }^{8}$ Standar ini dirancang untuk membantu organisasi mengidentifikasi ancaman spesifik, menilai kerentanan unik untuk menentukan risiko mereka, mengidentifikasi cara untuk mengurangi risiko ini dan kemudian menerapkan upaya pengurangan risiko sesuai dengan strategi organisasi.

Prinsip ISO 31000, misalnya, menyediakan kerangka kerja untuk perbaikan proses manajemen risiko yang dapat digunakan oleh perusahaan, terlepas dari ukuran organisasi atau sektor target. ISO 31000 dirancang untuk "meningkatkan kemungkinan pencapaian tujuan, meningkatkan identifikasi peluang dan ancaman, a dan secara efektif mengalokasikan dan menggunakan sumber daya untuk penanganan risiko," menurut situs web ISO. Meskipun ISO 3I000 tidak dapat digunakan untuk tujuan sertifikasi, ini dapat membantu memberikan panduan untuk audit risiko internal atau eksternal, dan memungkinkan organisasi untuk membandingkan praktik manajemen risiko mereka dengan benchmark yang diakui secara internasional.

8. Andrew M Cowan. December, 2013. Risk management standards, dalam www.skillmaker.edu.au, diakses, Kamis, 02 September 202I. 
Kerangka kerja standar manajemen risiko ISO 31000 meliputi: (I) ISO 31000:2009 - Prinsip dan Pedoman Implementasi; (2) ISO/IEC 3I0I0:2009 - Manajemen Risiko - Panduan Teknik Penilaian Risiko; dan (3) ISO 73:2009 Kosa Kata - Manajemen Risiko.

Standar ISO ini dirancang untuk membantu memandu organisasi dengan sejumlah untaian manajemen risiko yang berbeda. ISO merekomendasikan area target, atau prinsip berikut, yang harus menjadi bagian dari proses manajemen risiko secara keseluruhan:

- Proses harus menciptakan nilai bagi organisasi.

- Ini harus menjadi bagian integral dari proses organisasi secara keseluruhan.

- Ini harus menjadi faktor dalam proses pengambilan keputusan perusahaan secara keseluruhan.

- Ini harus secara eksplisit mengatasi ketidakpastian apa pun.

- Harus sistematis dan terstruktur.

- Ini harus didasarkan pada informasi terbaik yang tersedia.

- Itu harus disesuaikan dengan proyek.

- Itu harus memperhitungkan faktor manusia, termasuk potensi kesalahan.

- Itu harus transparan dan inklusif.

- la harus bisa beradaptasi dengan perubahan.

- Ini harus terus dipantau dan ditingkatkan.

Standar ISO dan lainnya seperti itu telah dikembangkan di seluruh dunia untuk membantu organisasi secara sistematis menerapkan praktik terbaik manajemen risiko.Tujuan akhir dari standar ini adalah untuk menetapkan kerangka kerja dan proses umum untuk menerapkan strategi manajemen risiko secara efektif.

Kesimpulan pentingnya adalah semakin organisasi siap memahami dan menerapkan standar manajemen risiko secara lebih dini dalam sistem manajemen risiko di organisasi mereka, maka organisasi itu akan semakin lincah mengeksploitasi kesempatan dan peluang yang ada dan pada saat yang sama sekaligus akan semakin tangguh menghadapi risiko yang terus berkembang, tanpa sempat terjadi 'crisis', apalagi 'disaster'pada organisasi tersebut.'

\subsubsection{Contoh manajemen risiko}

Salah satu contoh manajemen risiko adalah bisnis yang mengidentifikasi berbagai risiko yang terkait dengan pembukaan lokasi baru. Mereka dapat mengurangi risiko dengan memilih lokasi dengan banyak lalu lintas pejalan kaki dan persaingan yang rendah dari bisnis serupa di daerah tersebut.

9. BSN. 2018. "Standar Internasional Manajemen Risiko, perkembangan terkini dan implikasinya bagi Indonesia," dalam bsn.go.id, Jumat, 27 Juli 2018, diakses Rabu, 0I September 202I, pukul 19.5I WIB
Contoh lain adalah taman hiburan luar ruang yang mengakui bahwa bisnis mereka sepenuhnya bergantung pada cuaca. Untuk mengurangi risiko pukulan finansial yang besar setiap kali ada musim yang buruk, taman mungkin memilih untuk secara konsisten membelanjakan rendah dan membangun cadangan uang tunai.

Contoh lain adalah seorang investor yang membeli saham di perusahaan baru yang menarik dengan valuasi tinggi meskipun mereka tahu sahamnya bisa turun secara signifikan. Dalam situasi ini, penerimaan risiko ditampilkan saat investor membeli meskipun ada ancaman, merasakan potensi imbalan yang besar melebihi risikonya.

\section{I.7 Hubungan manajemen risiko dengan pandemi Covid- 19}

Apa hubungan manajemen risiko dengan pandemi Covid-19? Michael McAleer ${ }^{10}$ mengatakan, dalam konteks global, hubungan manajemen risiko dan pandemi Covid-19 tercermin dari Global Health Security (GHS) Index atau Indeks GHS.

Pada mulanya Indeks GHS adalah penilaian komprehensif, yang dikembangkan sebagai kolaborasi Ancaman Nuklir. Hal ini diinisiasi oleh Johns Hopkins Center for Health Security, dan Economist Intelligence Unit yang melakukan studi atas kemampuan membangun system keamanan kesehatan global di 195 negara. Kemudian, Indeks GHS mencantumkan negara-negara yang terbaik siap menghadapi epidemi atau pandemi (Global Health Security Index 2019).

Rata-rata skor Indeks GHS keseluruhan adalah 40,2 dari kemungkinan 100. Sementara negara-negara berpenghasilan tinggi melaporkan skor rata-rata 5I,9, Indeks menunjukkan bahwa secara kolektif, kesiapan internasional untuk epidemi dan pandemi tetap sangat lemah.

Secara keseluruhan, Indeks GHS menemukan kelemahan parah dalam kemampuan negara untuk mencegah, mendeteksi, dan merespons keadaan darurat kesehatan; kesenjangan parah dalam sistem kesehatan; kerentanan terhadap politik, sosial ekonomi, dan risiko lingkungan yang dapat mengacaukan kesiapsiagaan dan respons terhadap wabah; dan kurangnya kepatuhan dengan norma-norma internasional."

GHI Indeks 2019 menyebutkan 10 negara yaitu (10 USA (2) UK (3) Netherlands (4) Australia (5) Canada (6) Thailand (7) Sweden (8) Denmark (9) South Korea dan (10) Finland dengan indeks terbaik. Sementara Indonesia berada pada urutan ke-30, dan Korea Utara berada di peringkat

10. Michael McAleer. Editorial Prevention Is Better Than the Cure: Risk Management of COVID-I9 dalam Journal of Risk Financial Management. 2020, I3(3), 46; https:// doi.org 28 February 2020 / Published: 3 March 2020. Diakses, Kamis, 02 September 202I, pukul. I0.20WIB. 
193. Hingga saat ini, Korea Utara mengklaim tidak memiliki kasus Covid-19, yang hampir tidak dapat dipercaya. "

Pertanyaan yang kemudian muncul apakah model manajemen risiko yang dilakukan secara ala kadarnya pada sindrom virus corana seperti SARS dan MERS juga diterapkan pada Covid-19? Perlu diektahui, SARS menyebabkan 8.098 infeksi pada manusia yang dilaporkan dan 774 kematian di 32 negara selama 2002-2003, yang pada saat itu dipandang sebagai virus corona baru. Kemudian, Sindrom pernapasan Timur Tengah (MERS) disebabkan oleh pernapasan Timur Tengah syndrome coronavirus (MERS-CoV) MAXIMUS ALI PERAJAKA, NIDN : 033I086504, yang telah menyebabkan 2.492 infeksi pada manusia yang dilaporkan dan 858 kematian di 27 negara sejak diidentifikasi di Arab Saudi pada 20I2. Seperti SARS, MERS-CoV adalah penyakit baru virus corona pada saat itu.

Bukti yang dapat diandalkan berdasarkan banyak studi uji klinis eksperimental menunjukkan bahwa hingga saat ini tidak ada vaksin yang aman dan andal, atau kombinasi vaksin, untuk melindungi dari SARS dan MERS-CoV. Salah satu alasannya adalah epidemi SARS menghilang pada tahun 2003, jadi sepertinya tidak ada urgensi apapun dalam hal itu. Alasan lain adalah bahwa uji klinis mahal, terutama untuk komersial tujuan, sehingga beberapa uji klinis pada manusia belum menghasilkan vaksin yang aman dan efektif, karena disetujui oleh regulator nasional dan internasional, terhadap SARS dan MERS-CoV.

Merujuk keWu dan McCoogan (2020), Michael McAleer $(2020)^{12}$ menyatakan meskipun uji klinis hewan untuk menemukan vaksin dilaporkan telah dimulai di beberapa negara, Covid-19 berbeda dari SARS dan MERS-CoV dalam beberapa hal, termasuk kecepatan penularan, kemungkinan mutasi, persentase yang tidak diketahui dari diagnosis positif palsu dan negatif palsu, tingkat tidak diketahui infeksi ulang, dan sebagai pandemi daripada epidemi. Isu penting terkait manajemen risiko melalui uji klinis adalah apakah Covid- 19 adalah penyakit yang akan berperilaku lebih seperti SARS dan akhirnya menghilang, akan tetap berlanjut seperti MERS, atau akan terus berlanjut dan tidak terbatas. Dunia menunggu dengan penuh harap untuk pembaruan lebih lanjut, terutama berita yang menggembirakan mengenai pengembangan vaksin yang aman, efektif dan tepat waktu. Jadi, penerapan manajemen risiko dalam konteks pandemi Covid-19 bertalian dengan berbagai persyaratan untuk mengelola pandemi seperti membatasi jumlah tenaga kerja, mengurangi jam kerja dan meerapkan metode bekerja dari rumah (work from home/WFH).

II. Ibid

12. Ibid

\subsection{Pendidikan selama krisis COVID- 19}

\subsection{Situasi global}

Per 02 September 202I, UNESCO melalui en.unesco. org merilis data bahwa sebanyak 122,953,055 siswa terdampak pandemi Covid-1 9 di seluruh dunia. Angka ini jauh lebih baik dari keadaan pada Juli 2020 lalu. Belum pernah terjadi sebelumnya, pada 2020, masyarakata dunia menghadapi tantangan pendidikan global yang luar biasa. Selama gelombang pertama penguncian ruang gerak atas nama pandemic sebesar $80 \%$ siswa di seluruh dunia keluar dari sekolah dengan model pembelajaran tradisional pengajaran. Meskipun adaptasi di seluruh dunia untuk pengajaran jarak jauh melalui televisi, radio dan internet, II ada regional yang mencolok perbedaan kapasitas; 12 setidaknya $30 \%$ populasi siswa global tidak memiliki teknologi untuk berpartisipasi dalam digital dan pembelajaran siaran.

Sementara adaptif langkah-langkah yang memungkinkan sekolah dibuka Kembali akhirnya, banyak tantangan yang tersisa sepanjang gelombang berikutnya COVID-I 9 karena tidak efektif atau lambat tanggapan pemerintah. Penutupan sekolah memperparah ketidaksetaraan di kalangan kaum muda

Ketidaksetaraan dan di dalam masyarakat karena wanita muda dan orang-orang dari patung sosio-ekonomi yang kurang beruntung terkena pukulan paling keras. Siswa di rumah tangga berpenghasilan tinggi berpotensi diuntungkan dari lebih bertarget dan individual pengaturan pembelajaran,tetapi remaja yang kekurangan sumber daya berjuang untuk berpartisipasi dalam kesempatan pendidikan tanpa adanya konektivitas digital, dukungan orang dewasa atau ruang yang cukup untuk belajar di rumah.

Untuk lainnya, penutupan perbatasan rumit mobilitas Pendidikan. ${ }^{13}$ Sebagai contoh, data resmi UNESCO menyebutkan, hingga 07 Juli 2020, di kawasan Amerika Latin dan Karibia saja terdapat 33 negara melakukan penangguhan kelas tatap muka di semua tingkat pendidikan. Kebijakan tersebut melibatkan lebih 165 juta siswa. ${ }^{14}$

Selain mengganggu jalur pendidikan, penutupan sekolah berdampak pada pola makan dan gizi siswa, terutama di sektor yang paling rentan. Pada awal Juli 2020, 21 dari 33 negara di Amerika latin dan karibia terus menjalankan

13. I Chapter 3: Pandemials: Youth in an Age of Lost Opportunity dalam http://www3.weforum.org/ docs/WEF_The_Global_Risks_Report_2

14. COVID-I9 Report ECLAC-UNESCO. August 2020. "Educational measures during - Education in the timeof COVID-19", dalam repositorio.cepal.org diakses, Kamis, 02 September 202I, pukul I0.12 WIB. 
program pemberian makanan di sekolah dalam berbagai bentuk, terutama berupa pengiriman paket makanan untuk disiapkan di rumah, diikuti dengan penyediaan makan siang dan, pada tingkat lebih rendah, transfer tunai dan kupon makanan. Sebagian besar negara (29 dari 33 negara) telah menetapkan cara untuk terus menyediakan layanan pendidikan melalui berbagai modalitas pembelajaran jarak jauh. Sebagai contoh, 26 negara menerapkan bentuk pembelajaran berbasis internet dan 24 strategi pembelajaran jarak jauh offline, termasuk 22 negara yang menawarkan kedua modalitas (offline dan online), 4 memiliki modalitas online eksklusif dan 2 hanya modalitas offline. ${ }^{15}$

Salah satu risiko terbesar yang dihadapi perempuan dan anak perempuan dalam konteks pandemi adalah kekerasan. Tinjauan literatur baru-baru ini ${ }^{16}$ mengungkapkan tingkat kekerasan berbasis gender yang tinggi dalam berbagai epidemi pada masa lalu, dengan bentuk yang paling umum adalah kekerasan pasangan intim serta eksploitasi dan pelecehan seksual. Karantina yang berkepanjangan, kepadatan penduduk, ketidakpastian ekonomi dan peningkatan kemiskinan karena pandemi telah meningkatkan jumlah laporan insiden kekerasan berbasis gender di wilayah tersebut, termasuk tindakan kekerasan terhadap perempuan dan anak perempuan, yang menegaskan eksaserbasi kerentanan yang sudah ada sebelumnya. Peningkatan ini terjadi dalam keadaan di mana layanan yang bertanggung jawab atas kesehatan, keselamatan, dan perlindungan harus dialihkan ke respons pandemi. Demikian pula, perkiraan PBB (2020) menunjukkan bahwa untuk setiap tiga bulan penguncian berlanjut, akan ada 15 juta kasus tambahan kekerasan berbasis gender di seluruh dunia. Seiring dengan dampak fisik dan psikososial yang mendalam dari menyaksikan kekerasan, UNESCO (2019b) telah melaporkan bahwa pengalaman ini dapat memiliki implikasi langsung dan jangka panjang untuk pembelajaran dan kesejahteraan anak-anak dan remaja, serta untuk peningkatan kekerasan di sekolah.

Berbagai studi memperlihatkan, kekerasan berbasis gender juga terjadi pada masa pandemi Covid-19 ini.

Menurut UNESCO, tanggapan yang diterapkan oleh berbagai negara untuk menghhadapi pandemic Covid-19 telah menunjukkan inisiatif inovatif dan praktik yang menjanjikan, serta kemajuan penting dalam waktu singkat untuk memastikan kelangsungan pendidikan. Namun, jelas juga bahwa sistem pendidikan nasional menghadapi masalah dan tantangan sistemik yang memerlukan implementasi
15. Ibid
16. Ibid

strategi jangka menengah dan panjang berdasarkan Agenda 2030 dan SDG 4.

Inilah esensi dari definisi pendidikan kewarganegaraan global yang diajukan oleh UNESCO, yang berusaha tidak hanya untuk memberdayakan orang secara individu, tetapi juga untuk merebut dan membangun realitas mereka atas dasar penguatan hubungan sosial, melalui kepedulian terhadap diri sendiri dan orang lain, empati, rasa hormat. dan pengakuan keragaman, persahabatan dan solidaritas, sehingga berkontribusi pada koeksistensi dan kohesi sosial, yang diperlukan untuk membangun tindakan kolektif.

Tanggapan pendidikan nasional membantu mengidentifikasi tantangan prioritas ketika menerapkan langkah-langkah untuk memastikan kesinambungan, kesetaraan dan inklusi dalam pendidikan sementara kelas tatap muka ditangguhkan dan selama proses pembukaan kembali pusat pendidikan: (i) Kesetaraan dan inklusi: fokus pada yang paling rentan dan kelompok penduduk yang terpinggirkan - termasuk masyarakat adat, pengungsi dan migran, populasi yang paling tidak beruntung secara sosial ekonomi dan penyandang disabilitas-dan tentang keragaman seksual dan gender. (ii) Kualitas dan relevansi: fokus pada peningkatan isi kurikulum (dalam kaitannya dengan kesehatan dan kesejahteraan, khususnya) dan pada dukungan khusus untuk guru, memastikan kondisi kontrak dan kerja yang sesuai, pelatihan guru untuk pembelajaran jarak jauh dan kembali ke sekolah, dan dukungan sosial-emosional untuk bekerja dengan siswa dan keluarga mereka. (iii) Sistem pendidikan: kesiapan sistem pendidikan untuk merespon krisis, yaitu ketahanan di semua tingkatan. (iv) Interdisipliner dan pendekatan lintas sektoral: perencanaan dan pelaksanaan tidak hanya berfokus pada pendidikan, tetapi juga pada kesehatan, gizi dan perlindungan sosial. Dan, (v) Kemitraan: kerjasama dan kolaborasi antara berbagai sektor dan aktor untuk mencapai sistem yang terintegrasi, berfokus pada siswa dan tenaga kependidikan. Negara dan sistem pendidikan dan perlindungan sosialnya dihadapkan pada tantangan-tantangan ini, yang secara khusus mencerminkan kebutuhan akan pemenuhan hak atas pendidikan.

Dalam hal pembiayaan pendidikan, analisis awal oleh UNESCO International Institute for Educational Planning (IIEP, 2020) menunjukkan bahwa krisis akibat pandemi akan berdampak signifikan pada dua tingkatan: (i) Hilangnya belanja pendidikan selama ini krisis, serta biaya tambahan yang dihasilkan. (ii) Perkiraan penurunan sumber keuangan masa depan yang tersedia untuk sektor pendidikan.

\subsubsection{Situasi Indonesia}

Dampak pandemic Covid-19 atas dunia Pendidikan 
di Indonesia tampak nyata pada beberapa data dan fakta berikut ini. Data UNESCO memperlihatkan per 0 I September 2021, pandemi Covid-19 berdampak pada $68,265,767$ siswa, terdiri atas $33,247,703$ siswa perempuan dan 35,018,084 siswa pria. Dari sisi tingkat Pendidikan, Covid-19 berdampak atas, 5.090,25I siswa PAUD, 29,425.748 siswa Sekolah Dasar, 24,893,570 siswa SMP, dan 8.037,213 siswa SMA/K.

Sebelumnya, menurut laporan UNICEF, selama lebih dari satu tahun pandemi Covid-19, 80 juta anak dan remaja di Indonesia menghadapi dampak sekunder yang meluas pada pembelajaran, kesehatan, gizi, dan keamanan ekonomi, serta keamanan fisi dan mental mereka. ${ }^{17}$

UNICEF juga menemukan bahwa pandemi mengganggu pendidikan jutaan siswa, membatasi akses ke layanan kesehatan, nutrisi dan perlindungan kritis, dan menyebabkan keluarga berjuang untuk tetap tinggal bertahan secara finansial. Ketidaksetaraan yang ada telah diperburuk terutama yang terkait dengan gender, kemiskinan dan kecacatan - yang akan memiliki konsekuensi signifikan pada hasil perkembangan anak.

Menurut laporan tersebut, tiga dari empat rumah tangga di Indonesia mengalami penurunan pendapatan selama pandemi, dengan keluarga perkotaan yang terkena dampak lebih signifikan. Pada saat yang sama, hampir seperempat rumah tangga mengalami kenaikan biaya, meningkatkan risiko kerawanan pangan.

UNICEF menyebutkan pandemic Covid-19 mengakibatkan, lebih dari setengah juta lembaga anak usia dini (PAUD), sekolah dan universitas ditutup. Rata-rata waktu yang dihabiskan untuk pembelajaran jarak jauh bervariasi dari hanya 2,2 hingga 3,5 jam per hari di seluruh negeri. Penutupan sekolah juga meningkatkan risiko putus sekolah, menempatkan anak-anak putus sekolah pada risiko pernikahan anak yang lebih besar dan praktik-praktik berbahaya dan eksploitatif lainnya.

Demikian pula, terganggunya rutinitas sehari-hari telah mempengaruhi kesejahteraan mental dan emosional kaum muda. Hampir setengah dari semua rumah tangga telah melaporkan tantangan perilaku anak, dengan anak-anak sulit berkonsentrasi ( 45 persen), menjadi lebih marah ( 13 persen) dan sulit tidur (6,5 persen).

Laporan tersebut menemukan bahwa akses ke layanan kesehatan anak dan ibu telah menurun di seluruh negeri. Proporsi rumah tangga yang mengakses fasilitas kesehatan

17. UNICEF, August 2021: "80 million children in Indonesia face widespread impact from COVID-19 pandemic," dalam unicef.org. diakses pada Jumat, 03 September, pukul 09.20 WIB. untuk imunisasi, pengendalian kelahiran, perawatan kehamilan, persalinan dan layanan pasca melahirkan menurun tujuh persen secara nasional dan hampir 10 persen di daerah perkotaan pada tahun 2020.

Akses dan kepatuhan terhadap air bersih, sanitasi, dan praktik kebersihan dasar terus dibatasi di daerah berisiko tinggi penularan, seperti sekolah dan fasilitas perawatan kesehatan, menempatkan anak-anak dan kelompok rentan pada risiko yang lebih besar untuk tertular Covid-19.

Selain masalah di atas, Covid-19 meimbulkan dampak buruk berupa bertumbuhnya angka kekerasan terhadap anak-anak. Berdasarkan data dari Penetapan Perpanjangan Status Keadaan Tertentu Darurat Bencana (PPSKTDB) kekerasan pada anak awalnya mengalami penurunaan saat periode awal pandemi. Namun kejenuhan dan tuntutan kerja pada akhirnya meningkatkan angka kejadian kekerasan.

HM. Soeroyo Machfudz, dosen Fakultas Kedokteran Universitas Islam Indonesia $(2021)^{18}$ menyatakan perilaku anak selama pandemi sebagaian besar merasa bosan di rumah. School from home membuat mereka khawatir akan pelajaran, dan gelisah akan ekonomi keluarga. Kebanyakan korban kekerasan merasa takut untuk melapor karena kurangnya informasi untuk mengadu. Akses untuk mengadu rasanya sulit dijangkau untuk semua lapisan sosial.

Menurut Soeroyo, faktor utama penyebab kekerasan pada anak tidak jauh dari persoalan ekonomi dan kematangan dari kepribadian orang tua. Hal yang paling penting adalah spiritual. Rasa syukur yang dirasakan oleh orang tua, hubungan yang baik dengan Tuhan. Menurut dia, anak-anak yang mengalami kekerasan biasanya bersikap tertutup dan mudah marah.Tidak jarang akan memiliki kepribadian kasar. Aktivitas di sekolah biasanya akan menurun atau buruk. Gejala lain yang muncul adalah rasa takut yang tidak biasa.

Cara mencegah kekerasan pada anak karena pelaku bisa siapapun termasuk orang tua atau bahkan teman sebaya. Oleh karena orang tua harus memantau pertemanan anak-anak, karena pergaulan dengan orang yang terindikasi kekerasan juga akan berdampak buruk.

Hal senada disampaikan dr. Retno Sutomo, Sp.A (K), $\mathrm{PhD}$, dosen FKKMK UGM. Menurut dia, kekerasan pada anak selama pandemi ini memiliki trend baru yaitu melalui cyberbullying, termasuk melalui sosial media. Hal tersebut didukung data yang menunjukkan penggunaan sosial media atau gadget tidak digunakan untuk tujuan belajar. ${ }^{19}$

\footnotetext{
18. Seminar yang berjudul "Kekerasan Pada Anak di Masa Pandemi Covid-19,” Minggu, 13 Juni 2021.
}

16. Ibid. 


\section{METODE PENELITIAN}

Studi ini dilakukan dengan meggunakan metode penelitian kualitatif. Pembahasan dan analisis kualitatif manajemen risiko pandemi Covid-1 9 di bidang Pendidikan (sekolah) melibatkan pengidentifikasian ancaman (atau peluang), seberapa besar kemungkinannya terjadi, dan potensi dampaknya jika terjadi. Data untuk analisis ini diperoleh melalui pengamatan dan penelaahan dokumen (studi kepustakaan), bukan penelitian lapangan.

Tidak seperti analisis manajemen risiko kuantitatif, yang menerapkan nilai numerik dan menggunakan data yang dapat diverifikasi, analisis manajemen risiko kualitatif beroperasi dalam ruang "gambaran besar" yang lebih umum, dan menghasilkan data deskriptif.

Analisis risiko kualitatif mengklasifikasikan risiko menurut kemungkinan dan dampaknya. Hal ini memudahkan organiasasi (sekolah) untuk menentukan risiko mana yang harus menjadi fokus organisasi - risiko yang termasuk dalam kategori kemungkinan dan dampak tertinggi. Dari sana, manajer risiko di sekolah dapat memanfaatkan data untuk menangani risiko pandemi Covid-19 secara lebih rinci dan akurat.

Namun, mengingat manajemen risiko adalah proses sebuah multi-langkah maka analisis risiko kualitatif memiliki keterbatasan karena bersifat subyektif (tergantung pada persepsi orang yang melakukan penelitian). Untuk meminimalkan subjektivitas, maka analisis risiko kualitatif harus melibatkan pandangan dari orang/organiasi berbeda. Itulah sebabnya, dalam tulisan ini, peneliti menggunkan pendapat bukan saja dari otoritas Pendidikan (Kemendikburistek) dan peneliti/pakar Pendidikan Indonesia, melainkan juga rekomendasi dari UNESCO dan Victoria State Government, Asutralia. Dengan demikian diharapkan analisa dan rekomendasi manajemen risiko di dunia Pendidikan (sekolah) di Indonesia menjadi memadai dan lebih akurat.

\section{PEMBAHASAN}

Menghadapi dampak pandemi Covid-19 atas dunia pendidikan, pemerintah, melalui Kementerian Pendidikan dan Kebudayaan dan Ristek (Kemenbudristek) telah memembuat kebijakan dan panduan yang lebih berfokus pada anak. Pemerintah misalnya telah mengeluarkan berbagai kebijakan dan inisiatif untuk menghadapi kendala pembelajaran di masa pandemi Covid-19, seperti revisi surat keputusan bersama (SKB) Empat Menteri yang telah diterbitkan tanggal 7 Agustus 2020, untuk menyesuaikan kebijakan pembelajaran di era pandemi saat ini. Selain itu, sekolah diberi fleksibilitas untuk memilih kurikulum yang sesuai dengan kebutuhan pembelajaran siswa di masa pandemi, sebagaimana ditetapkan dalam Keputusan Menteri Pendidikan dan Kebudayaan terkait kurikulum pada masa darurat. ${ }^{20}$

Mempertimbangkan kebutuhan pembelajaran, berbagai masukan dari para ahli dan organisasi serta mempertimbangkan evaluasi implementasi SKB Empat Menteri, Pemerintah melakukan penyesuaian terkait pelaksanaan pembelajaran di zona kuning dan hijau dapat melaksanakan pembelajaran tatap muka dengan penerapan protokol kesehatan yang sangat ketat.

Bagi daerah yang berada di zona oranye dan merah dilarang melakukan pembelajaran tatap muka di satuan pendidikan dan tetap melanjutkan Belajar dari Rumah (BDR). Berdasarkan data per 23 Agustus 2020 dari http:// covid 9.go.id terdapat sekitar 48 persen peserta didik masih berada di zona merah dan oranye. Sementara itu, sekitar 52 persen peserta didik berada di zona kuning dan hijau.

Prosedur pengambilan keputusan pembelajaran tatap muka di zona kuning dan hijau, kata Mendikbud, tetap dilakukan secara bertingkat seperti pada SKB sebelumnya. Pemda/kantor/kanwil Kemenag dan sekolah memiliki kewenangan penuh untuk menentukan apakah daerah atau sekolahnya dapat mulai melakukan pembelajaran tatap muka.

Mendikbud juga menekankan, bahwa sekalipun daerah sudah dalam zona hijau atau kuning, serta Pemda dan sekolah sudah memberikan izin pembelajaran tatap muka, keputusan terakhir ada di orang tua. Apabila orang tua tidak mengizinkan putra-putrinya mengikuti pembelajaran tatap muka, maka anaknya tetap melanjutkan belajar dari rumah.

Tahapan pembelajaran tatap muka satuan pendidikan di zona hijau dan zona kuning dalam revisi SKB Empat Menteri dilakukan secara bersamaan pada jenjang pendidikan dasar dan menengah dengan pertimbangan risiko kesehatan yang tidak berbeda untuk kelompok umur pada dua jenjang tersebut. Sementara itu untuk PAUD dapat memulai pembelajaran tatap muka paling cepat dua bulan setelah jenjang pendidikan dasar dan menengah.

Memang hingga akhir tahun ajaran 2020/20I, sekolah-sekolah di Indonesia melakukan pembelajaran jarak jauh dengan kurikulum yang disesuaian. Namun, hal ini tidak berjalan sesuai harapan karena infrastruktur telekomunikasi, seperti tidak semua anak memiliki computer atau

20. Sekretariat GTK. “Kebijakan Kemendikbud di Masa Pandemi” dalam gtk.kemdikbud.go.id. Diakses Jumat, 03 September 202I, pukul I3.I2 WIB. 
smartphone dan akses yang tidak merata ke koneksi Internet, yang menghasilkan distribusi sumber daya dan strategi yang tidak merata, terutama mempengaruhi kelompok berpenghasilan rendah atau lebih rentan.

Survei terhadap 23.015 orangtua murid di DKI Jakarta menunjukkan, pembelajaran jarak jauh sarat masalah, mulai dari keterbatasan perangkat, gangguan internet, hingga menyebabkan anak frustrasi.Akan tetapi, mayoritas responden berharap, pembukaan sekolah tatap muka baru dilakukan setelah pandemi mereda dan anak-anak mendapatkan vaksinasi. Survei ini dilakukan LaporCovid-19 bersama Fakultas Psikologi Universitas Indonesia dan dipresentasikan secara daring, Kamis (5/8/202I). Survei dilakukan pada periode 30 April hingga 15 Mei 202I dengan metode convenience sampling. Penyebaran survei dilakukan secara daring dengan dukungan Pemerintah Provinsi DKI Jakarta. ${ }^{21}$

Berdasarkan data dan fakta tersebut berbagai pihak mendorong agar pemerintah segera memberlakukan pembelajaran tatap muka Ketika pandemic Covid- 19 sudah mulai terkendali. Pemerintah, dalam hal ini Kemendibudristek didesak pula untuk segera mengidentifikasi tingkat kehilangan pembelajaran untuk menginformasikan program dan kampanye pembelajaran yang mengejar ketertinggalan. Namun, pada sisi lain ada pula kalangan yang meminta untuk bersikap hati-hati dan melakukan perhitungan yang matang sebelum memberlakukan pembelajaran tata muka. Kelompok ini meminta pemerintah tetap fokus melnjutkan layanan kesehatan, termasuk kampanye mengejar imunisasi, sambil memvaksinasi populasi.

\section{I Manajemen risko di dunia pendidikan da- lam konteks nasional}

Berhadapan dengan pandemi Covid-19 yang belum sepenuhnya dapat dikendalikan, pemerintah diharapkan memanfaatkan manajemen risiko di bidang pendidikan. Atinya, pemerintah perlu menerapkan langkah-langkah perlindungan yang mendeteksi, mencegah dan menanggapi kekerasan terhadap anak dan kelompok rentan lainnya dan menyediakan layanan dukungan kesehatan mental dan psikososial untuk semua anak dan pengasuh.

Untuk memitigasi pandemi Covid-10 di lingkungan sekolah, Badan Kesehatan Dunia (WHO) mengeluarkan panduan ${ }^{22}$ yang berisikan antara lain mendorong pemerintah untuk memperkuat sistem adaptif untuk menyediakan

21. Ahmad Arif, "Pembelajaran Jarak Jauh Bermasalah, Pembukaan Sekolah Tetap Tunggu Pandemi Terkendali" dalam www.kompas.id, 05 Agustus 202I, Bdk. Gangsar Parikesi, "Beragam Masalah Sekolah di Rumah," dalam koran.tempo.co,, 07 Agustus 2021.

22. WHO. 2020. Coronavirus disease (COVID-19): Schools, dalam www. who.int, September 18, 2020. dan memantau layanan gizi untuk menghindari gangguan layanan selama masa krisis.

Pemerintah dituntut untuk meningkatkan dan mempercepat investasi dalam fasilitas sanitasi dan cuci tangan di sekolah-sekolah, dan memperkuat kapasitas untuk mempromosikan praktik cuci tangan yang benar di masyarakat, rumah tangga, terutama di sekolah.

Bahkan, pemerintah didesak untuk melakukan studi tentang efek intervensi mitigasi risiko di sekolah, seperti membatasi kontak antar anak, memakai masker (di luar atau di dalam kelas terus menerus), menutup area dan kegiatan (bermain, olahraga, kantin) dan meningkatkan ventilasi, masih jarang. Oleh karena itu, ada kebutuhan mendesak untuk studi empiris - daripada pemodelan - yang dilakukan dengan baik untuk menilai berbagai efek dari berbagai tindakan yang diterapkan di lingkungan sekolah. Intervensi perlu dievaluasi untuk tujuan dan potensinya.

Mengenakan masker adalah masalah yang kompleks dan harus dipertimbangkan sebagai salah satu paket tindakan untuk melindungi dan mencegah penularan. Pedoman sementara yang diterbitkan oleh WHO merekomendasikan bahwa anak-anak hingga usia 5 tahun tidak boleh memakai masker. Untuk anak-anak berusia 6-II tahun, pendekatan berbasis risiko harus diambil, dengan mempertimbangkan tingkat penularan masyarakat, kemampuan untuk menjaga jarak fisik dan ventilasi. Di atas usia 12 tahun, prinsip yang sama harus diterapkan seperti yang diterapkan untuk orang dewasa di ruang dalam ruangan mana pun di mana orang-orang bersama untuk jangka waktu yang lama dalam konteks penularan komunitas yang sedang berlangsung. ${ }^{23}$

Pedoman WHO tentang cuci tangan menyarankan bagaimana sekolah dapat menerapkan tindakan yang sederhana namun sangat efektif ini dengan sebaik-baiknya. Tindakan yang saat ini diadopsi di beberapa negara - misalnya, menyemprot lingkungan sekolah dengan disinfektan, disinfeksi berlebihan (bukan membersihkan) permukaan dan mencuci tangan secara berlebihan - memiliki dampak rendah atau tidak ada nilai untuk pengendalian infeksi, dan mungkin memiliki efek yang merugikan.

Untuk mendukung hal di atas WHO juga menyarankan:

- sekolah harus memiliki strategi mitigasi risiko;

- negara harus memastikan strategi-strategi ini dengan hati-hati menyeimbangkan kemungkinan manfaat, dan bahaya bagi, kelompok usia anak-anak yang lebih muda dan lebih tua ketika membuat keputusan tentang penerapan tindakan pencegahan dan pengendalian infeksi;

- semua hal di atas perlu diimbangi dengan alternatif yang lebih buruk dari penutupan sekolah;

23. Ibid 
setiap tindakan yang diperkenalkan oleh sekolah harus mengikuti protokol standar untuk implementasi; dan

- negara harus meninjau paket tindakan secara teratur dan memperbarui sesuai dengan bukti yang muncul; tindakan-tindakan yang dianggap tidak berpengaruh atau berbahaya harus dihentikan, dan semua tindakan harus dibuktikan dengan keadilan. ${ }^{24}$

Oleh karena dampak ekonomi dari pandemi COVID-19 masih berkembang dan pemulihannya mungkin memakan waktu lebih lama, dunia Pendidikan menerima konsekuensi anggaran yang sebenarnya yang cukup berat. Disebutkan terdapat selisih besaran anggaran antara tahun 202I dan tahun sebelumnya yang berkisar Rp5 triliun antara realisasi anggaran pada tahun 2020, dipengaruhi oleh reorganisasi di lingkup internal kementerian. Selain itu juga dikarenakan adanya kebijakan yang perlu diambil untuk merespons pandemi Covid-19. ${ }^{25}$ Oleh karena itu, penting bagi pemerintah untuk menghitung biaya sistem pendidikan nasional dan memprioritaskan pengeluaran, serta untuk memastikan perlindungan pendidikan sebagai hak asasi manusia yang mendasar dan untuk memanfaatkan potensi transformatif pendidikan, tidak hanya untuk membangun sistem yang tangguh tetapi juga untuk berkontribusi pada pemulihan sosial. ${ }^{26}$

Singkatnya, pandemi Covid-19 saat ini menimbulkan tantangan signifikan bagi pendidikan dan sistem sosial na24. Ibid

25. www.kemdikbud.go.id edisi 27 Januari 202 I menulis artikel berjudul, "Pagu Anggaran Kemendikbud Tahun 202I Sebesar Rp8I,5 Triliun". Dalam artikel tersebut disebutkan antara lain:"Rapat kerja perdana Kementerian Pendidikan dan Kebudayaan (Kemendikbud) bersama Komisi X DPR RI di tahun 202I menetapkan 20 persen dari APBN atau sebesar Rp550 triliun, dialokasikan untuk dana pendidikan. Dari 20 persen anggaran tersebut, Kemendikbud mengelola sebanyak I4,8 persen atau sekitar Rp8I,5 triliun. Proporsi terbesar dari anggaran Rp8I,5 triliun yang dikelola Kemendikbud berada di pendanaan wajib, yaitu sebesar Rp3I, I 3 triliun. Pendanaan wajib tersebut meliputi pembiayaan Program Indonesia Pintar untuk 17,9 juta siswa, Kartu Indonesia Pintar Kuliah (KIP) termasuk ADIK yang menargetkan I.I02 juta mahasiswa, tunjangan guru non-PNS dengan target sasaran 363.000 guru, Bantuan Operasional Perguruan Tinggi Negeri (BOPTN) dan Bantuan Pendanaan PTN Badan Hukum (BPPTN-BH) Pendidikan Tinggi untuk 75 PTN, BOPTN vokasi untuk 43 PTN, serta pengembangan destinasi pariwisata untuk empat destinasi wisata. Sesuai amanat undang-undang, selain Kemendikbud, anggaran pendidikan turut dikelola oleh berbagai kementerian/lembaga lainnya yang menjalankan fungsi pendidikan, seperti Kementerian Agama (Kemenag). Sejalan dengan itu, Undang-undang Pemerintahan Daerah juga mengamanatkan bahwa anggaran pendidikan ditransfer ke daerah secara langsung. Anggaran tersebut terdiri dari Dana Alokasi Umum (DAU) dan Dana Alokasi Khusus (DAK)."

26. Syah, R. H. (2020). Dampak Covid-19 pada Pendidikan di Indonesia: Sekolah, Keterampilan, dan Proses Pembelajaran. SALAM: Jurnal Sosial Dan Budaya Syar-I, 7(5). https://doi.org//0.15408/sjsbs.v7i5.153/4, diakses pada Sabtu, 04 September, pukul 19.20WIB. sional yang harus ditangani secara terkoordinasi. Ini juga menawarkan pelajaran berharga tentang prioritas nyata kehidupan sebagai bagian dari komunitas. Saat ini, tantangan dan pelajaran ini menawarkan prospek untuk memikirkan kembali tujuan pendidikan dan perannya dalam menopang kehidupan dan martabat manusia, sehingga tidak ada yang tertinggal. Dengan kata lain, ketika negara mampu meminimalkan risiko dan memberikan keamanan pada lembaga pendidikan selama pandemi Covid-19, krisis ini memberikan peluang yang belum pernah terjadi sebelumnya untuk meningkatkan ketahanan sistem pendidikan nasional dan mengubahnya menjadi sistem yang adil dan inklusif yang membantu memenuhi komitmen kolektif yang dibuat. dalam Agenda 2030 untuk Pembangunan Berkelanjutan.

\subsection{Manajemen risko pandemi Covid-19 dalam konteks sekolah}

Penerapanan manajemen risiko pada skala nasional oleh pemerintah melalui Kemendikbudristek, tidaklah memadai, tetapi perlu ditindaklanjuti pada tingkat operasional sekolah.

Untuk ini, ada beberapa tawaran model manajemen risiko di masa pandemi Covid-19. Salah satu model manajemen risiko yang dapat dipakai adalah model yang dikembangkan oleh Pelatihan dan Pendidikan yang dikembangkan di State Victoria Government, Amerika Serikat. Selain mudah diaplikasikan, model tersebut terbukti berhasil meminimalisasi dampat pandemi Covid-19 di sekolah-sekolah berasrama di kawasan tersebut. Model ini dapat diadopsi oleh sekolah-sekolah berasrama di Indonesia, seperti Pondok Pesantren dan Seminari, sekolah-sekolah berasrama yang rentan terhadap pandemic Covid-19.27 Model tersebut terdiri atas dua bagian sebagai berikut:28

Bagian A: Identifikasi risiko dan rencana minimalisasi

Template di bawah ini akan membantu Sekolah mengidentifikasi dan menerapkan strategi manajemen risiko untuk memperlambat penyebaran virus corona (COVID-19). Memang setiap sekolah berasrama akan menghadapi masalah dan tantangan yang berbeda. Oleh karena itu setiap

27. M Ridlo Susanto ."Marak Covid-19 klaster pesantren, salah siapa?" dalam https://www.aa.com.tr. Diakses diakses Sabtu, 4 September 202I, pukul 18.10 WIB. Bdk. Nansianus Taris | Editor Dheri Agriesta. "I67 Siswa dan 8 Tenaga Pendidik di Seminari BSB Maumere Positif Covid-19, “ Kompas.com - 30/04/202I, I4:12 WIB, diakses Sabtu, 4 September 202I, pukul 19.02 WIB.

28. Victoria State Goverment Corona Viros(COVID-19) Risk Assessment and Mitigation Planning for School Boarding Presmies and Medium Term Resdential Pprograms, /is.vic.edu.au 


\begin{tabular}{|c|c|c|c|c|c|}
\hline $\begin{array}{l}\text { Strategi Manaje- } \\
\text { men Riskiko }\end{array}$ & Contoh aksi & $\begin{array}{l}\text { Aksi yang } \\
\text { akan dilter- } \\
\text { apkan }\end{array}$ & $\begin{array}{l}\text { Aksi yang sudah } \\
\text { diterapkan }\end{array}$ & Kapan & $\begin{array}{l}\text { Penanggung } \\
\text { jawab }\end{array}$ \\
\hline $\begin{array}{l}\text { Strategi } \\
\text { pengurangan } \\
\text { penularan untuk } \\
\text { siswa }\end{array}$ & $\begin{array}{l}\text { - Mengejar berbagai strategi untuk mendukung fisik } \\
\text { - Menjaga jarak antara semua siswa dan staf. } \\
\text { - Mematuhi persyaratan masker wajah untuk siswa. } \\
\text { - } \text { Pertimbangkan untuk mengadakan kegiatan di luar dan mendoron makan di luar, jika cuaca memungkinkan. }\end{array}$ & & & & \\
\hline \multirow[t]{2}{*}{$\begin{array}{l}\text { Strategi } \\
\text { pengurangan } \\
\text { penularan } \\
\text { untuk staf }\end{array}$} & $\begin{array}{l}\text { - Perkuat jarak fisik antara orang dewasa. } \\
\text { - Patuhi persyaratan masker wajah untuk staf. } \\
\text { - Terapkan batas kepadatan di area staf, misalnya staf } \\
\text { - ruang makan siang, dan area mana pun yang diakses oleh pengunjung. } \\
\text { - Memberikan pendidikan dan pelatihan bagi staf tentang } \\
\text { - penggunaan yang tepat dari alat pelindung diri } \\
\text { - (PPE) saat mengelola seseorang yang memajang gejala virus corona } \\
\text { (COVID-19), di mana relevan. } \\
\text { - Mengadakan pertemuan di luar dan mendorong staf untuk makan luar } \\
\text { ruangan cuaca memungkinkan. } \\
\text { - Melakukan pembersihan lingkungan fasilitas secara teratur. }\end{array}$ & & & & \\
\hline & $\begin{array}{l}\text { - Pastikan penyediaan fasilitas keber-sihan yang memadai dan persediaan, } \\
\text { termasuk sabun, air mengalir danpembersih tangan. } \\
\text { - Meningkatkan ventilasi. } \\
\text { - Resirkulasi udara harus dihilangkan atau diminimalkan dengan menyetel } \\
\text { AC untuk menggunakan udara eksternal daripada daur ulang. Memastikan } \\
\text { pintu dan jendala tetap mudah dibuka dan ditutup. Membiarkan pintu selalu } \\
\text { terbuka } \\
\text { - (kecuali pintu kamar tidur dan kamar mandi). } \\
\text { - Mencatat pengunjung dan kontraktor ke } \\
\text { - fasilitas (serta menyimpan catatan semua siswa) } \\
\text { - dan staf). } \\
\text { - Menerapkan pencegahan infeksi yang tepat dan kontrol di fasilitas klinik/ } \\
\text { rumah sakit, termasuk: } \\
\text { Penggunaan masket yang tepat dan pasokan APD dan pengaturan jarak } \\
\text { social yang ketat. persyaratan jarak. }\end{array}$ & & & & \\
\hline & & & & & \\
\hline
\end{tabular}

pimpinan sekolah harus mempertimbangkan dan menerapkan tindakan yang sesuai dengan kondisi masing-masing Bagian B: Perencanaan untuk Tanggap Darurat

Berdasarkan identifikasi risiko dan perencanaan minimalisasi di atas, pihak sekolah harus mengembangkan dan mendokumentasikan strategi yang direncanakan untuk menanggapi skenario seperti: sebagai kasus tunggal atau ganda dan/atau kontak dekat diidentifikasi di antara siswa dan staf. Pihak sekolah juga harus melakukan perencanaan skenario untuk penutupan sementara sebagian atau seluruh fasilitas asrama jika terdapat siswa ataupun staf kasus yang terkonfirmasi Covid- 19. Dan, siapa yang bertanggung jawab melapor ke Satgas Covid- 19.29

Template di atas sejalan dengan dengan pedoman yang disarankan BPNP kepada sejumlah pesantren di Jawa Timur guna mengantisipasi penyebaran Covid- 19. Pertama, melakukan test cepat Covid-19 kepada santri yang akan masuk ke wilayah pesantren. Kedua, memperhatikan kebersihan lingkungan pesantren, mulai dari kebersihan ka- mar tidur, peralatan makan, dan juga peraltan ibadah. Ketiga, perlu menerapkan protocol Kesehatan, yakni dengan memakai masker, menjaga jarak dan menghindari kerumunan, serta mencuci tangan menggunakan sabu di air mengalir selama berada di lingkungan pesentren.

Keempat, santri yang mengalami gejala ringan, hendaknya dininta segera melapor ke pengelola pensantren untuk segera mendapat Tindakan cepat, sehingga jika ditemukan Covid- 19 maka penangangan menjadi jauh lebih mudah. Kelima, membatasi jumlah pengujung agar mampu menekan intensitas pertemuan dengan pihak luar yang berpotensi menularkan vurus corona. Jadwal kunjugan dari wali santri pun dibatasi serta diberikan jarak sat bertemu dengan santri, serta dilarang bersentuhan fisik. ${ }^{30}$

30. Abdul Aziz," Mencegah COVID-I 9 di pesantren," dalam antaranews. com, Senin, 24 Mei 202I, diakses Sabtu, 04 September 202I, pukul 20:53 WIB Bdk. Syah, R. H. (2020). Dampak Covid- 19 pada Pendidikan di Indonesia:Sekolah, Keterampilan, dan Proses Pembelajaran. SALAM: Jurnal Sosial Dan Budaya Syar-I, 7(5). https://doi.org// 0.15408/sjsbs. v7i5. 15314.

29. Ibid 


\begin{tabular}{|c|c|c|c|c|}
\hline Strategi tanggap darurat & Hal yang perlu diperhatikan & Kapan & $\begin{array}{l}\text { Siapa penanggu- } \\
\text { jawabnya }\end{array}$ & $\begin{array}{l}\text { Aksi terlaksana/ } \\
\text { Tidak }\end{array}$ \\
\hline $\begin{array}{l}\text { Perkembangan dari rencana } \\
\text { aksi indi-vidu untuk siswa dan } \\
\text { staf }\end{array}$ & $\begin{array}{l}\text { - Detail tentang informasi yang harus disertakan dalam tindakan individu } \\
\text { rencana untuk siswa dan staf tersedia dalam saran untuk sekolah untuk } \\
\text { mengelola risiko penularan virus corona (COVID-19) di sekolah asrama } \\
\text { - Berkonsultasi dengan keluarga siswa mengenai perkembangan rencana } \\
\text { aksi individu untuk siswa. }\end{array}$ & & & \\
\hline $\begin{array}{l}\text { Perencanaan skenario tunggal } \\
\text { dan jamak bila berhadapan } \\
\text { dengan kasus yang dikon-fir- } \\
\text { masi dan/ atau kon-tak dekat, } \\
\text { di sekolah berasrama; apakah } \\
\text { sekolah tetap terbuka }\end{array}$ & $\begin{array}{l}\text { - Menerapkan rencana aksi individu untuk siswa dan anggota staf yang } \\
\text { terkena dampak. } \\
\text { - Tindakan untuk melindungi kesehatan dan kesejahteraan siswa dan staf } \\
\text { lain di dalam lingkungan asrama sekolah } \\
\text { - Rencana komunikasi untuk siswa, staf, orang tua dan pengunjung. }\end{array}$ & & & \\
\hline $\begin{array}{l}\text { Perencanaan skenario untuk } \\
\text { ka-sus tunggal dan jamak yang } \\
\text { dikon-firmasi dan/atau kontak } \\
\text { dekat, di mana asrama sekolah } \\
\text { dan apa-kah tempat perlu } \\
\text { ditutup sementara atau tidak }\end{array}$ & $\begin{array}{l}\text { - Menerapkan rencana aksi individu untuk siswa dan staf yang terkena } \\
\text { dampak Covid-19; } \\
\text { - Tindakan untuk melindungi kesehatan dan kesejahteraan siswa dan staf } \\
\text { lain di dalam lingkungan asrama sekolah } \\
\text { - - Rencana komunikasi yang terencana }\end{array}$ & & & \\
\hline
\end{tabular}

\subsection{Manajemen risiko pasca pandemi Covid- I 9}

Penerapan manajemen risiko di sekolah, memang tidak boleh berhenti hanya saat pandemi berlangsung, tetapi juga harus dilanjutkan setelah pandemi Covid-19 mereda (pasca pandemi Covid-19). Sebab, hingga kini belum ada ahli yang memastikan bahwa Covid-19 tidak muncul lagi, setelah ia mereda.

WHO melalui artikel berjudul 'Coronavirus disease (COVID-19):Schools'(2018) menyatakan, meski pandemi Covid-19 sudah mereda di seluruh dunia, setiap negara, lebih khusus otorita Pendidikan di tingkat nasional mampun lokal, terutama pengelola dan/atau penyelenggara sekolah harus tetap menerapkan manajemen risiko.

Pertanyaannya adalah, apa yang harus dipantau setelah pembukaan kembali sekolah, pasca pandemi Covid-19? Menurut WHO, hal itu yang harus dillakukan adalam memantau:

- Seberapa efektivitas pelaporan gejala, pemantauan, pengujian cepat, dan penelusuran kasus yang dicurigai;

- Efek kebijakan dan ukuran pada tujuan pendidikan dan hasil pembelajaran dampak dari kebijakan dan tindakan terhadap kesehatan dan kesejahteraan anak, saudara kandung, staf, orang tua, dan anggota keluarga lainnya;

- Tren putus sekolah setelah pencabutan pembatasan yang diberlakukan selama pandemi Covid-19 berlangsung;

- Jumlah kasus pada anak-anak dan staf di sekolah, dan frekuensi wabah berbasis sekolah di wilayah administrasi lokal;

- Penilaian dampak pengajaran jarak jauh pada hasil belajar.

Berdasarkan apa yang dipelajari dari pemantauan ini, otoritas Pendidikan dan penyelenggara/pengelola sekolah dapat memodifikasi lebih lanjut harus dilakukan untuk terus menyediakan lingkungan yang paling aman bagi anak-anak dan staf di sekolah. Jadi, penerapan manajemen risiko pandemi Covid- I 9 berbasis sekolah adalah kebijakan, perencanaan dan praktik yang terus berkelanjutan, demi terjaminannya keamanan, kesehatan dan keselamatan para siswa.

\section{Kesimpulan}

Dari uraian di atas, penulis dapat menyimpulkan bahwa otoritas Pendidikan (Kemendikburistek) dan sekolah-sekolah di Indonesia sudah mulai menerapkan manajemen risiko untuk mencegah penyebaran Covid- I 9 lebih luas lagi. 
Setiap sekolah, khususnya sekolah berasrama yang pernah menjadi klaster penyebaran Covid-19 seperti Pesantren dan Seminari, telah menjalani manajemen risiko sesuai dengan arahan BNBP sehingga pandemi Covid-1 9 dapat diatasi.

Satu hal yang masih harus didorong adalah agar penerapan manajemen risiko di sekolah-sekolah melalui template yang jelas dan baku sebagaimana yang direrapkan di luar negeri seperti di Victoria State di Australia. Sebab, penerapan manajemen risiko yang dengan template yang jelas dapat memudahkan evaluasi, supervise dan asesmen pengukuran tangkat keberhasilannya.
Penerapan manajemen risiko demikian, tidak hanya dibutuhkan pada masa pandemi sekarang, melainkan juga tetap dibutuhkan pada masa pasca pandemi, Ketika kegiatan pembelajaran tatap muka mulai dibuka Kembali. Hal tersebut untuk mencegah agar jangan sampai kemudian sekolah Kembali menjadi klaster baru penyebaran Covid- 19 gelombang berikutnya. Sebab, hingga kini para ahli di bidangg virologi dan pandemi, belum dapat memastikan dan memberikan jaminan bahwa Covid-19 tidak akan muncul lagi setelah berhasil dikendalikan. 


\section{DAFTAR PUSTAKA}

Abdul Aziz, "Mencegah COVID-19 di pesantren," dalam antaranews.com, Senin, 24 Mei 202I, diakses Sabtu, 04 September 202I, pukul 20:53 WIB Syah, R. H. (2020). Dampak Covid-19 pada Pendidikan di Indonesia: Sekolah, Keterampilan, dan Proses Pembelajaran. SALAM: Jurnal Sosial Dan Budaya Syar-I, 7(5). https:// doi.org/I0.15408/sjsbs.v7i5.153/4.

Ahamad Arif,"Pembelajaran Jarak Jauh Bermasalah, Pembukaan Sekolah Tetap Tunggu Pandemi Terkendali" dalam www.kompas.id, 05 Agustus 202I,

Andrew M Cowan. December, 2013. Risk management standards, dalam www.skillmaker.edu.au, diakses, Kamis, 02 September 2021.

BSN. 2018. "Standar Internasional Manajemen Risiko, perkembangan terkini dan implikasinya bagi Indonesia," dalam bsn.go.id, Jumat, 27 Juli 2018, diakses Rabu, 01 September 202I, pukul I9.5I WIB

Chapter 3: Pandemials: Youth in an Age of Lost Opportunity dalam http://www3.weforum.org/ docs/WEF_ The_Global_Risks_Report_2

COVID-19 Report ECLAC-UNESCO. August 2020. "Educational measures during - Education in the timeof COVID-19", dalam repositorio.cepal.org diakses, Kamis, 02 September 202I, pukul 10.12 WIB.

Gangsar Parikesi, "Beragam Masalah Sekolah di Rumah," dalam koran.tempo.co,, 07 Agustus 202I

Keith Blacker, Patrick McConnell .2016."People Risk Management A Practical Approach to Managing the Human Factors That Could Harm Your Business." Kogan Page, Limited. Hal 15.

Michael McAleer. Editorial Prevention Is Better Than the Cure: Risk Management of COVID-19 dalam Journal of Risk Financial Management. 2020, 13(3), 46; https:// doi.org 28 February 2020 / Published: 3 March 2020. Diakses, Kamis, 02 September 202I, pukul. 10.20 WIB.

M Ridlo Susanto."Marak Covid- 19 klaster pesantren, salah siapa?" dalam https://www.aa.com.tr. Diakses diakses
Sabtu, 4 September 202I, pukul 18.10WIB.

Nansianus Taris. Editor Dheri Agriesta. "I67 Siswa dan 8 Tenaga Pendidik di Seminari BSB Maumere Positif Covid-19, “Kompas.com - 30/04/202I, I4: I2 WIB, diakses Sabtu, 4 September 202I, pukul 19.02 WIB.

National Institute of Standards and Technology, July 2002, Risk Management Guide for Information Technology System, Special Publication 800-30, hal. I.

Rufina Scott (202I), "Risk Management: Objectives, Advantages And Disadvantages" dalam http://processnews. blogspot.com/2019, diakses, Kamis, 02 September 2021, pukul 16.13.WIB.

Sekretariat GTK. "Kebijakan Kemendikbud di Masa Pandemi” dalam gtk.kemdikbud.go.id. Diakses Jumat, 03 September 2021, pukul I3.12 WIB

Seminar yang berjudul "Kekerasan Pada Anak di Masa Pandemi Covid-19," Minggu, 13 Juni 202I.

Syah, R. H. (2020). Dampak Covid- 19 pada Pendidikan di Indonesia: Sekolah, Keterampilan, dan Proses Pembelajaran. SALAM: Jurnal Sosial Dan Budaya Syar-I, 7(5). https://doi.org/I0.15408/sjsbs.v7i5. I53 I4, diakses pada Sabtu, 04 September, pukul 19.20 WIB.

Tatang Guritno. "Epidemiolog Minta Pemerintah Siapkan Manajemen Risiko Sekolah Tatap Muka Kompas.com - 31/03/2021. Diakses, Rabu, 0I September 202I, pukul 17.00.

UNICEF, August 2021: "80 million children in Indonesia face widespread impact from COVID-19 pandemic," dalam unicef.org. diakses pada Jumat, 03 September, pukul 09.20 WIB.

Victoria State Goverment Corona Viros(COVID-19) Risk Assessment and Mitigation Planning for School Boarding Presmies and Medium Term Resdential Pprograms, /is.vic.edu.au

WHO. 2020. Coronavirus disease (COVID-19): Schools, dalam www.who.int, September 18, 2020.

www.kemdikbud.go.id edisi 27 Januari 202I, "Pagu Anggaran Kemendikbud Tahun 202I Sebesar Rp8I,5 Triliun". 